\title{
Thymoquinone supplementation reverses lead-induced oxidative stress in adult rat testes
}

\author{
Aymen Mabrouk and Hassen Ben Cheikh \\ Laboratory of Histology and Cytogenetic (Research unit of Genetic, Genotoxicity and Child Disease UR12ES10), Faculty \\ of Medicine, 5019 Monastir, Tunisia
}

\begin{abstract}
The purpose of the present study was to investigate the potential protective effect of thymoquinone (TQ), the major active ingredient of volatile oil of Nigella sativa seeds, against $\mathrm{Pb}$-induced testicular oxidative stress. Adult male rats were randomized into four groups: control group which received no treatment, $\mathrm{Pb}$ group was exposed to $2000 \mathrm{ppm} \mathrm{Pb}$ acetate in drinking water, $\mathrm{Pb}$ - TQ group was co-treated with Pb plus TQ (5 mg/kg b.w./day, p.o.) and TQ group receiving only TQ (5 mg/kg b.w./day, p.o.). All treatments were applied for 5 weeks. Pb treatment induced oxidative stress status in testes as evidenced by a significant decrease in the antioxidant enzymes activities such as superoxide dismutase, glutathione peroxidase and catalase, and in the reduced glutathione content and in a significant increase in the level of malondialdehyde. Interestingly, TQ supplementation completely reversed these biochemical changes caused by $\mathrm{Pb}$ to the control values. In conclusion, our results suggest, for the first time, that TQ is very efficient in preventing $\mathrm{Pb}$-induced testicular oxidative stress. This study will open new perspectives for the clinical use of TQ in $\mathrm{Pb}$ intoxication.
\end{abstract}

Key words: Lead - Thymoquinone - Oxidative stress - Testes — Rat

\begin{abstract}
Abbreviations: CAT, catalase; GPX, glutathione peroxidase; GSH, reduced glutathione; LPO, lipid peroxidation; MDA, malondialdehyde; ROS, reactive oxygen species; SOD, superoxide dismutase; TQ, thymoquinone.
\end{abstract}

\section{Introduction}

Lead $(\mathrm{Pb})$ is a non-essential metal that occurs naturally in the environment. The levels of $\mathrm{Pb}$ in the environment are constantly increasing due to industrial activities (Wasowicz et al. 2001). Pb is present in plastic, paints, ceramics, glass, water pipes, insecticides and leaded gasoline (Henretig 2002). $\mathrm{Pb}$ poisoning has been reported since the discovery of $\mathrm{Pb}$ thousands of years ago and it remains a major health issue worldwide (Karrari et al. 2012). The manifestations of $\mathrm{Pb}$ poisoning in humans are nonspecific. They may include anemia (Khalil-Manesh et al. 1994), nephropathy (Ng et al. 2013) and infertility (Patocka and Cerný 2003). Air, water, soil, food and consumer products are the major routes of human exposure to $\mathrm{Pb}$ (Hammond 1977).

Correspondence to: Aymen Mabrouk, Laboratory of Histology and Cytogenetic (Research unit of Genetic, Genotoxicity and Child Disease UR12ES10), Faculty of Medicine, 5019 Monastir, Tunisia E-mail: mabroukaymen20@yahoo.fr
Bolin et al. (2006) reported that Pb-exposed mammals showed the generation of reactive oxygen species (ROS), stimulation of lipid peroxidation (LPO) and inhibited antioxidant defense system suggesting that oxidative stress is one possible mechanisms of action of $\mathrm{Pb}$ toxicity. Oxidative stress represents an imbalance between the production of ROS and a biological system's antioxidant defense mechanism (Singh et al. 2004). Pb-induced oxidative stress results in tissue injury via oxidative damage to macromolecules like lipids, proteins and DNAs (Kruk 1998).

$\mathrm{Pb}$ is able to cross blood-testis barrier, and thus the testis is vulnerable to $\mathrm{Pb}$ toxicity (Fair and Ricklefs 2002; Snoeijs et al. 2004). The toxic effect of $\mathrm{Pb}$ on reproduction is pervasive affecting basically all aspects of the reproductive system (Abdel-Moniem et al. 2010). Testicular effects of $\mathrm{Pb}$ are suggested to be related to generation of ROS, resulting in oxidative cellular damage (Marchlewicz et al. 2004).

It is essential to find an appropriate approach to prevent $\mathrm{Pb}$ toxicity. The current approved treatment for $\mathrm{Pb}$ poisoning is to administer chelating agents (thiol chelators and other 
complex ions) that form an insoluble complex with the metal and remove it from tissue, but most of these chelating agents cause many side effects and have no effect on low levels of exposure (Flora et al. 1995). The fact that $\mathrm{Pb}$ exposure induces an excessive increase of ROS suggests that antioxidants could be used as an alternative therapy (Wang et al. 2006).

Medicinal plants nowadays are an important source of drug synthesis and at least third of current drugs are derived from plants (Bent 2008). Thymoquinone (TQ) (2-isopropyl5-methyl-1,4-benzoquinone), the main active component of the essential oil of Nigella sativa seeds, has various pharmacological effects such as analgesic (Çelik et al. 2014), anti-diabetic (Abdelmeguid et al. 2010), anti-inflammatory (Ammar et al. 2011) and anti-cancer properties (Woo et al. 2011). TQ is reported to possess strong antioxidant properties (Rifaioglu et al. 2013). TQ supplementation considerably protected several organs against oxidative damage induced by a variety of free radical generating agents including aflatoxin B1 evoked hepatotoxicity (Nili-Ahmadabadi et al. 2011), nephropathy produced by gentamicin (Yaman and Balikci 2010) and ethanol-induced gastric mucosal injury (Kanter et al. 2006). The high potency and low systemic toxicity of TQ make it a promising alternative to conventional therapeutic drugs (Lupidi et al. 2010).

The influence of TQ on heavy metals-induced testicular toxicity has not been studied till now. Therefore, the aim of the present study was to investigate whether oral supplementation of TQ protects against $\mathrm{Pb}$-induced testicular oxidative stress.

\section{Materials and Methods}

\section{Materials}

Lead acetate trihydrate $\left[\left(\mathrm{C}_{2} \mathrm{H}_{3} \mathrm{O}_{2}\right)_{2} \mathrm{~Pb} \times 3 \mathrm{H}_{2} \mathrm{O}\right]$, thymoquinone (2-isopropyl-5-methyl-1,4-benzoquinone), trichloroacetic acid (TCA), thiobarbituric acid (TBA) and 5,5'dithio-bis-(2-nitrobenzoic acid) (DTNB) were purchased from Sigma-Aldrich Chemical Co. (St. Louis, MO, USA). All other chemicals were of the best analytical grade.

\section{Animals}

Healthy adult (4-months-old) male Wistar rats, weighing 200-230 g, obtained from the Tunisian Society of Pharmaceutical Industries, were used in this study. The animals were housed in plastic cages (free from any source of chemical contamination) with free access to tap water (free from $\mathrm{Pb}$ ) and standard diet. The rats were kept at $22 \pm 3^{\circ} \mathrm{C}$, in natural light/dark cycle, with 55\% humidity and under ventilation system. Experiments were started after the animals were allowed to adapt to the laboratory conditions for a week. This study was approved by the local Ethical Committee, Faculty of Medicine, University of Monastir, Tunisia, and run in accordance to the statements of European Union regarding handling of experimental animals (86/609/EEC).

\section{Experimental design}

After an acclimation period, the rats were randomly divided into 4 groups of 8 animals each. Rats were treated for 5 weeks as follows: control group received tap water, $\mathrm{Pb}$ group received an aqueous solution containing $2000 \mathrm{ppm} \mathrm{Pb}$ acetate $(0.2 \%$, w/v) (Çaylak et al. 2007, 2008), Pb-TQ group was cotreated with $\mathrm{Pb}$ (as in $\mathrm{Pb}$ group) plus TQ ( $5 \mathrm{mg} / \mathrm{kg}$ b.w./day, gastric gavage) (Alenzi et al. 2010; El-Sayed 2011) and TQ group received tap water and were given TQ ( $5 \mathrm{mg} / \mathrm{kg}$ b.w.) by gastric tube daily (between 8:00 and 9:00 a.m.).

At the end of the treatment period, the animals were euthanized by exsanguination through cardiac puncture under diethyl ether anesthesia.

\section{Tissue collection and testicular extracts preparation}

The testes were removed quickly from rats, cleared of the adhesive tissues and washed in ice-cold $0.9 \%(\mathrm{w} / \mathrm{v})$ $\mathrm{NaCl}$ solution. Fragments of organs were homogenized in 10 volumes of ice-cold phosphate-buffered saline (PBS: $136.75 \mathrm{mmol} / 1 \mathrm{NaCl}, 2.68 \mathrm{mmol} / \mathrm{K} \mathrm{KCl}, 10.14 \mathrm{mmol} / \mathrm{l}$ $\mathrm{Na}_{2} \mathrm{HPO}_{4}, 1.76 \mathrm{mmol} / \mathrm{K} \mathrm{KH}_{2} \mathrm{PO}_{4}, \mathrm{pH}$ 7.4) and the homogenates were centrifuged at $3500 \times g$ for $15 \mathrm{~min}$ at $4^{\circ} \mathrm{C}$. The supernatant fractions were collected and stored at $-80^{\circ} \mathrm{C}$ until biochemical analysis.

\section{Determination of antioxidant enzyme activities}

Superoxide dismutase (SOD) activity was determined in the testicular samples as previously described by Arthur and Boyne (1985) by using Ransod Kit (Randox laboratories Ltd., Crumlin, UK). Xanthine and xanthine oxidase were used to generate superoxide anion radicals $\left(\mathrm{O}_{2}{ }^{--}\right)$, which react with 2-(4-iodophenyl)-3-(4-nitrophenol)-5-phenyltetrazolium chloride (INT) to form a red formazan dye. The SOD activity is then measured by the degree of inhibition of this reaction. Changes in the absorbance were measured spectrophotometrically at $505 \mathrm{~nm}$ during the first $3 \mathrm{~min}$ of the reaction. Enzyme activity in the sample was calculated from a standard curve and was expressed as units/g of wet testicular tissue. One unit of SOD is defined as the amount of enzyme required to inhibit the reduction of INT by $50 \%$ under the conditions of the assay.

Glutathione peroxidase (GPX) activity was measured in the testicular samples according to the method of Paglia and Valentine (1967) by using Ransel Kit (Ramdox laboratories Ltd., Crumlin, UK). In this method, GPX catalyses the oxidation of reduced glutathione (GSH) by cumene hydroper- 
oxide. In the presence of glutathione reductase (GR) and $\mathrm{NADPH}$, the oxidized glutathione (GSSG) is immediately converted to the reduced form with a concomitant oxidation of NADPH to NADP ${ }^{+}$. The decrease in absorbance at $340 \mathrm{~nm}$ was measured spectrophotometrically for $2 \mathrm{~min}$, and the results were expressed as units/g of wet testicular tissue. One unit of GPX is defined as the amount of enzyme necessary to covert $1 \mu \mathrm{mol}$ of NADPH to $\mathrm{NADP}^{+}$in $1 \mathrm{~min}$ at $37^{\circ} \mathrm{C}$.

Catalase (CAT) activity was determined according to the ferrithiocyanate method of Cohen et al. (1996) by the disappearance of hydrogen peroxide $\left(\mathrm{H}_{2} \mathrm{O}_{2}\right)$ that was measured calorimetrically with ferrous ions and thiocyanate on a microplate reader. CAT activity was determined by the difference in the absorbance at $492 \mathrm{~nm}$ per unit of time and was expressed in terms of the first order reaction rate constant $(\mathrm{k})$ and weight of wet testicular tissue sample as follows: $\mathrm{U} / \mathrm{g}_{\text {tissue }}=\mathrm{k} / \mathrm{g}_{\text {tissue }}=\left[\ln \left(\mathrm{A}_{1} / \mathrm{A}_{2}\right) /\left(\mathrm{t}_{2}-\mathrm{t}_{1}\right)\right] / \mathrm{g}_{\text {tissue }}$, where $\ln$ is the natural $\log , A_{1}$ and $A_{2}$ are the observed mean absorbance at $492 \mathrm{~nm}$ at two time points, $\mathrm{t}_{1}=15 \mathrm{~s}$ and $\mathrm{t}_{2}=1 \mathrm{~min}$. One unit of CAT is defined as the quantity of enzyme that decomposes $1 \mu \mathrm{mol}$ of $\mathrm{H}_{2} \mathrm{O}_{2} / \mathrm{min}(\mathrm{pH} 7.0)$ at $25^{\circ} \mathrm{C}$.

\section{Determination of GSH}

GSH was determined spectrophotometrically by the method previously described by Ellman (1959). In brief, $1 \mathrm{ml}$ of supernatant was taken after precipitating $0.5 \mathrm{ml}$ of testes sample with $2 \mathrm{ml}$ of $5 \%(\mathrm{w} / \mathrm{v})$ TCA. To this, $0.5 \mathrm{ml}$ of Ellman's reagent $(0.019 \%(\mathrm{w} / \mathrm{v})$ DTNB in $1 \%(\mathrm{w} / \mathrm{v})$ sodium citrate) and $3 \mathrm{ml}$ of phosphate buffer ( $1 \mathrm{~mol} / \mathrm{l}, \mathrm{pH} 8.0)$ were added. The absorbance of TNB (5-thio-2-nitrobenzoic acid), product formed when sulphydryl (SH) groups react with DTNB, was measured at $412 \mathrm{~nm}$ against an appropriate blank without sample. The concentration of GSH was obtained by standard curve and expressed as $\mathrm{mg} / \mathrm{g}$ of wet testicular tissue.

\section{Estimation of LPO}

LPO was estimated indirectly by measuring the malondialdehyde (MDA), an end product of LPO. The MDA level was determined spectrophotometrically by using the method of TBA which measures MDA-reactive products (Placer et al. 1966), as described by Todorova et al. (2005). In brief, the testicular samples were mixed with $0.9 \%(\mathrm{w} / \mathrm{v}) \mathrm{NaCl}$ and $25 \%(\mathrm{w} / \mathrm{v}) \mathrm{TCA}$, and centrifuged at $2000 \times \mathrm{g}$ for $15 \mathrm{~min}$. The supernatant was then mixed with $0.5 \%(\mathrm{w} / \mathrm{v}) \mathrm{TBA}$ and heated in a water bath at $95^{\circ} \mathrm{C}$ for $1 \mathrm{~h}$. After cooling, the absorbance of the coloured complex formed (MDA-TBA) was measured at $532 \mathrm{~nm}$ against an appropriate blank without sample. The concentration of MDA was calculated by using the molar extinction coefficient of thiobarbituric acid reactants (TBARS; $\left.1.56 \times 10^{5} \mathrm{~mol}^{-1} \cdot \mathrm{cm}^{-1}\right)$. LPO was expressed as nmol MDA/g of wet testicular tissue.

\section{Statistical analysis}

Data were expressed as mean \pm SEM. Comparisons between the groups were performed by the Student's $t$-test. Differences were considered statistically significant at $p$ value $<0.05$.

\section{Results}

\section{Antioxidant enzymes}

As shown in Fig. 1A-C, the testicular activities of SOD, GPX and CAT in rats receiving TQ alone were not significantly
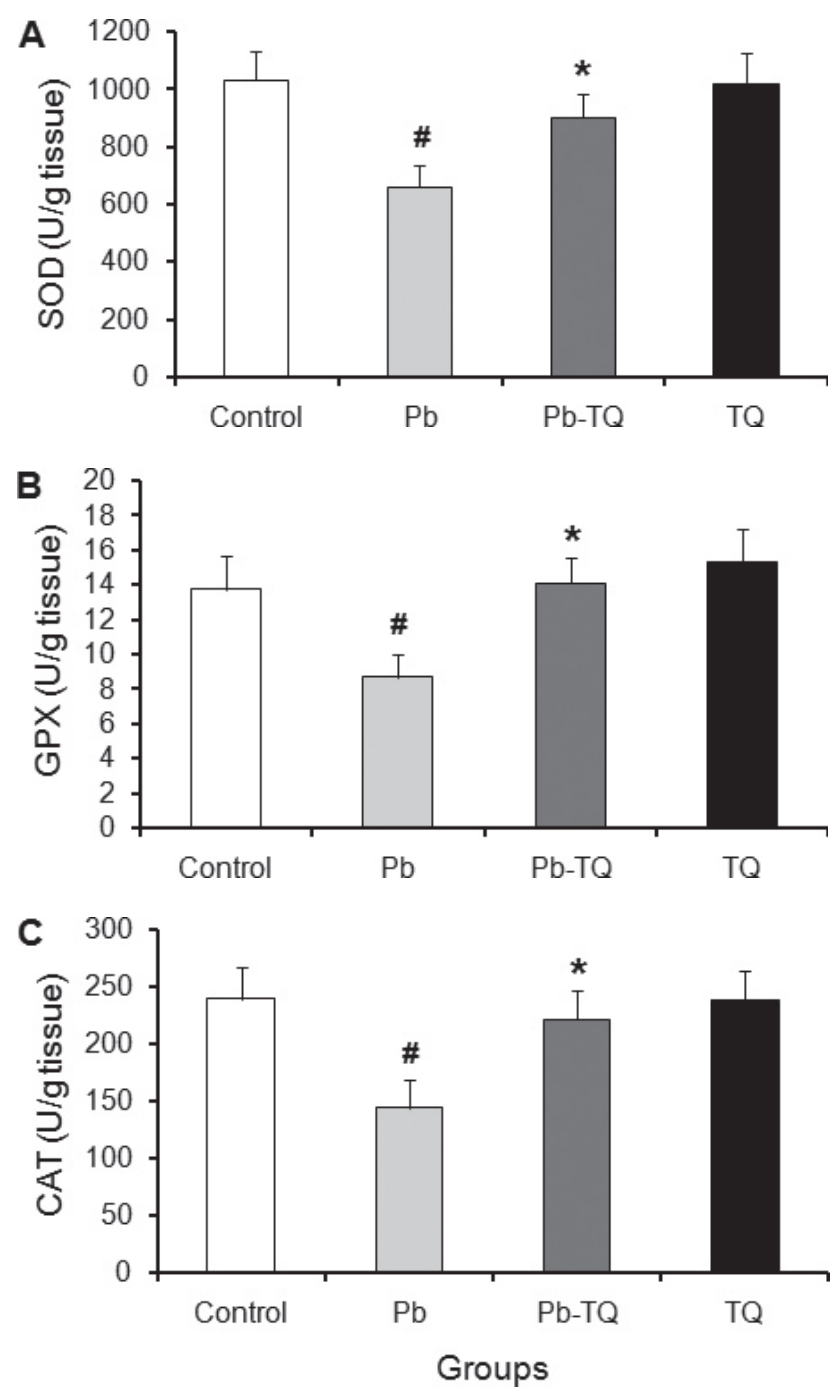

Figure 1. Effects of lead (Pb), thymoquinone (TQ) and their coexposure on the testicular activities of superoxide dismutase (SOD, A), glutathione peroxidase (GPX, B) and catalase (CAT, C) in rats after 5 weeks. Values are expressed as mean \pm SEM of 8 animals. ${ }^{\#} p<0.05 v$ s. the control group; ${ }^{*} p<0.05 v$ s. the $\mathrm{Pb}$ group. 
different $(p>0.05)$ from those of control group, while following $\mathrm{Pb}$-treatment, the activities of these enzymes were significantly decreased $(p<0.05)$ by $36.23 \%, 36.72 \%$ and $40.02 \%$, respectively. Interestingly, TQ co-administration completely prevented the deleterious effect of $\mathrm{Pb}$ on the activities of these antioxidant enzymes. In fact, in rats cotreated with $\mathrm{Pb}$ and TQ, the activities of SOD, GPX and CAT significantly increased $(p<0.05)$ by $36.76 \%, 62.4 \%$ and $54.15 \%$, respectively in relation to $\mathrm{Pb}$-intoxicated rats to reach similar values $(p>0.05)$ than control group.

\section{GSH and MDA levels}

Results presented in Fig. 2 indicated that the administration of TQ alone had no significant effect $(p>0.05)$ on testicular GSH level compared to that of the control rats. In contrast, $\mathrm{Pb}$-exposure caused a significant decrease $(p<0.05)$ of about $45.62 \%$ in the concentration of this non-enzymatic antioxidant in relation to control rats. This effect was totally reversed when $\mathrm{Pb}$-treated animals received simultaneously TQ.

Testicular MDA level remained unchanged $(p>0.05)$ in TQ-treated rats, while it increased significantly $(p<0.05)$ by $51.65 \%$ after $\mathrm{Pb}$-treatment compared to control group. TQ supplementation also perfectly inhibited the testicular LPO induced by $\mathrm{Pb}$ administration. In fact, rats co-treated with $\mathrm{Pb}$ and TQ showed similar MDA level $(p>0.05)$ than control animals (Fig. 3).

\section{Discussion}

In spite of the strict regulatory measures that are taken by most countries to decrease environmental $\mathrm{Pb}$ burden, human $\mathrm{Pb}$ exposure continues to remain an important public health issue particularly in developing countries with a lack of public control. In the present study, we adopted an in vivo experimental animal model to investigate the protective role of TQ against $\mathrm{Pb}$-induced testicular toxicity in terms of oxidative stress.

The metalloproteins SOD, GPX and CAT are the major antioxidant enzymes (Boots et al. 2008). Their activities were used to assess oxidative stress in cells. SOD catalyzes the dismutation of $\mathrm{O}_{2}{ }^{\cdot-}$ to $\mathrm{H}_{2} \mathrm{O}_{2}$ and $\mathrm{O}_{2}$. Because $\mathrm{H}_{2} \mathrm{O}_{2}$ is still harmful to cells, CAT and GPX further catalyze the decomposition of $\mathrm{H}_{2} \mathrm{O}_{2}$ to water. In the reaction catalyzed by GPX, GSH is oxidized to GSSG, which can then be reduced back to GSH by GR (Dröge 2002; Lee and Choi 2003). In the present study, we found that treatment by $\mathrm{Pb}$ for 5 weeks significantly decreased the activities of SOD, GPX and CAT in the rat testis. Other investigators reported similar observations (Abdel-Moniem et al. 2010; Dorostghoal et al. 2013). Like other metals, $\mathrm{Pb}$ has a high affinity for $\mathrm{SH}$ groups, mercaptides are formed with the $\mathrm{SH}$ group of cysteine, and less stable complexes with other amino acid side chains (Vallee and Ulmer 1972). $\mathrm{Pb}$ is shown to alter antioxidant activities by inhibiting functional SH groups in several enzymes such as SOD, GPX and CAT (McGowan and Donaldson 1986; Chiba et al. 1996; Hsu and Guo 2002). Since Pb competes with trace elements for binding to proteins, SOD, GPX and $\mathrm{CAT}$ are potential targets for $\mathrm{Pb}$ toxicity because these antioxidant enzymes depend on various essential trace elements for proper molecular structure and enzymatic activity. SOD requires copper and zinc for its activity. Copper ions appear to have a functional role in the reaction by undergoing alternate oxidation and reduction, where zinc ions seem to stabilize the enzyme instead of having a role in the catalytic cycle (Halliwell and Gutteridge 1989). On the contrary, Pb has been reported to induce copper and zinc deficiency in tissue (Barán 1994). Schrauzer (1987) indicated antagonistic effects between $\mathrm{Pb}$ and selenium, resulting in reduced selenium

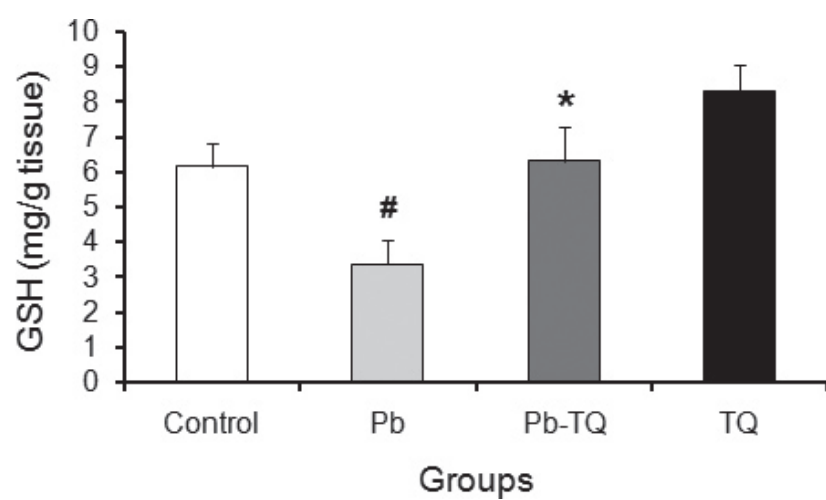

Figure 2. Effects of lead $(\mathrm{Pb})$, thymoquinone (TQ) and their coexposure on the testicular level of reduced glutathione (GSH) in rats after 5 weeks. Values are expressed as mean \pm SEM of 8 animals. ${ }^{\#} p<0.05 v$ s. the control group; ${ }^{*} p<0.05 v$ s. the $\mathrm{Pb}$ group.

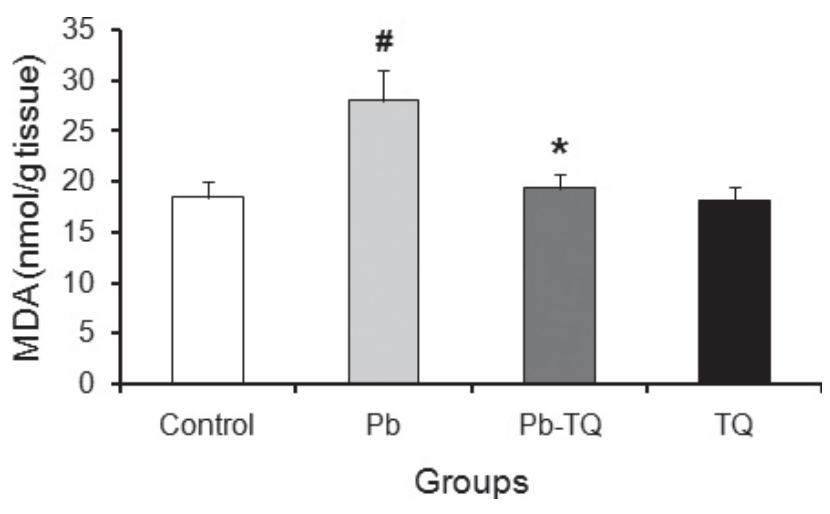

Figure 3. Effects of lead (Pb), thymoquinone (TQ) and their coexposure on the testicular level of malondialdehyde (MDA) in rats after 5 weeks. Values are expressed as mean \pm SEM of 8 animals. ${ }^{\#} p<0.05$ vs. the control group; ${ }^{\star} p<0.05$ vs. the $\mathrm{Pb}$ group. 
uptake that may affect GPX activity that requires selenium as a cofactor. CAT is an important antioxidant enzyme having heme as the prosthetic group, but $\mathrm{Pb}$ is known to reduce the absorption of iron in the gastrointestinal tract and to inhibit the heme biosynthesis (Dresel and Falk 1954). Therefore, the inhibition of functional SH groups by irreversible binding of $\mathrm{Pb}$ and the competition of $\mathrm{Pb}$ with essential trace elements can explain in part the decrease in the antioxidant enzyme activities found in the present work.

GSH is a tripeptide containing cysteine that has a reactive $\mathrm{SH}$ group with reductive potency. Accordingly, GSH plays a vital role in the protection of cells against oxidative stress. It can act as a nonenzymatic antioxidant by direct interaction of the SH group with ROS, or it can be involved in the enzymatic detoxification reactions for ROS, as a cofactor or a coenzyme (Sivaprasad et al. 2002, 2004). GSH possesses carboxylic acid groups, amino group, $\mathrm{SH}$ group, and two peptide linkages as sites for reactions of metals (Christie and Costa 1984). In agreement with previous investigations studying the effect of $\mathrm{Pb}$ on adult rats testes (Abdel-Moniem et al. 2010; Ayinde et al. 2012), our data show that Pbtreatment significantly lowered the gonad GSH level. The reduction in concentration of GSH may be due to the high affinity of $\mathrm{Pb}$ to the $\mathrm{SH}$ groups of this tripeptide (Christie and Costa 1984; Korsrud and Meldrum 1988), thereby interfering with its antioxidant activity. $\mathrm{Pb}$ can also decrease the concentration of GSH by inhibiting the activities of enzymes involved in GSH metabolism, such as GR, glucose-6-phosphate dehydrogenase (G6PD) and glutathione S-transferase (GST), via blocking their SH groups (Neal et al. 1999; Sivaprasad et al. 2004).

It has been suggested that the main mechanism involved in $\mathrm{Pb}$ toxicity is oxidative stress caused by inducing the generation of ROS (Pande et al. 2001), which in turn cause LPO (Ahamed and Siddiqui 2007). LPO inactivates cell constituents by oxidation or causes oxidative stress by undergoing radical chain reaction, ultimately leading to loss of membrane integrity (Abdel-Wahhab and Aly 2005). In the present investigation, LPO as measured by the amount of MDA was significantly elevated in the testes of $\mathrm{Pb}$-treated rats. Salawu et al. (2009) and Dorostghoal et al. (2013) reported the same outcome in $\mathrm{Pb}$ intoxication. An increased generation of highly ROS was also observed in the testes after $\mathrm{Pb}$ exposure (Acharya et al. 2003; Marchlewicz et al. 2007). It seems that $\mathrm{Pb}$ does not readily undergo the redox reaction characteristic of transition metals and directly is not able to enhance the ROS formation, but it stimulates the LPO indirectly through depletion of cell's antioxidant defense system (Patra et al. 2001; Gordon et al. 2002) as evidenced, in the current study, by the significant decline in the activities of the key antioxidant enzymes and the GSH level. The impaired antioxidant ability of the cell resulted in decreased scavenging of ROS, a highly reactive oxidizing agents such as $\mathrm{H}_{2} \mathrm{O}_{2}, \mathrm{O}_{2}{ }^{--}$, hydroxyl radical $\left(\mathrm{OH}^{\bullet}\right)$ and singlet oxygen $\left({ }^{1} \mathrm{O}_{2}\right)$. At high levels, the ROS might be responsible for cellular injuries and oxidative damages to critical biomolecules, such as membrane lipids, proteins and nucleic acids (Zhang et al. 2009). Because of its high content of polyunsaturated membrane lipids that are sensitive to oxidative attack, testicular tissue becomes an important target of LPO (Mishra and Acharya 2004).

However, extensive research is now focusing on herbal products as an alternative medicine, no evidence has been reported in the literature regarding the role of TQ against $\mathrm{Pb}$ testicular toxicity. In the present study, TQ supplementation suppresses completely $\mathrm{Pb}$-induced testicular oxidative stress as evidenced by the normalization of LPO level, GSH concentration, and SOD, GPX and CAT activities in the group co-treated with $\mathrm{Pb}$ plus TQ. This potent antioxidant activity of TQ has been found in other experimental models. For instance, Sayed-Ahmed and Nagi (2007), Sayed-Ahmed et al. (2010) and Nagi et al. (2011) reported that oral administration of TQ totally abolished renal, hepatic and cardiac oxidative stress induced respectively by gentamicin, diethylnitrosamine and cyclophosphamide in rats as demonstrated by complete reversal of LPO degree, GSH level, and SOD, GPX and CAT activities. The mechanisms of TQ action are not yet clear. Nevertheless, TQ is known to reduce oxidative stress not only through direct antioxidant effect, but also indirectly. Mansour et al. (2002) and Badary et al. (2003) reported that TQ acts as strong ROS scavenger. Recent studies have demonstrated that TQ supplementation increases the expression of antioxidant genes of SOD, GPX and CAT in rat liver (Ismail et al. 2010; Sayed-Ahmed et al. 2010).

In conclusion, our study indicates that subchronic exposure to $\mathrm{Pb}$ causes oxidative stress in adult rat testes. These data, therefore, provide insight into the mode of action of testicular toxicity of $\mathrm{Pb}$. Additionally, our results suggest, for the first time, that TQ oral supplementation, at a safe dose, is very effective in protecting rats against $\mathrm{Pb}$-induced testicular oxidative stress. This spectacular protection makes TQ as a promising agent in a variety of conditions where cellular damage is a consequence of oxidative stress. This work will open new perspectives for the clinical use of TQ in $\mathrm{Pb}$ intoxication.

Acknowledgement. This work was supported by funds allocated to the Research Unit of Genetic, Genotoxicity and Child Disease (UR12ES10) by the Tunisian Ministry of Higher Education and Scientific Research.

Conflict of interest. The authors declare that there are no conflicts of interest.

\section{References}

Abdelmeguid N. E., Fakhoury R., Kamal S. M., Al Wafai R. J. (2010): Effects of Nigella sativa and thymoquinone on biochemical and 
subcellular changes in pancreatic $\beta$-cells of streptozotocininduced diabetic rats. J. Diabetes 2, 256-266 http://dx.doi.org/10.1111/j.1753-0407.2010.00091.x

Abdel-Moniem A. E., Dkhil M. A., Al-Quraishy S. (2010): Protective role of flaxseed oil against lead acetate induced oxidative stress in testes of adult rats. Afr. J. Biotechnol. 9, 7216-7223

Abdel-Wahhab M. A., Aly S. E. (2005): Antioxidant property of Nigella sativa (black cumin) and Syzygium aromaticum (clove) in rats during aflatoxicosis. J. Appl. Toxicol. 25, 218-223 http://dx.doi.org/10.1002/jat.1057

Acharya U. R., Rathore R. M., Mishra M. (2003): Role of vitamin C on lead acetate induced spermatogenesis in swiss mice. Environ. Toxicol. Pharmacol. 13, 9-14 http://dx.doi.org/10.1016/S1382-6689(02)00107-2

Ahamed M., Siddiqui M. K. (2007): Low level lead exposure and oxidative stress: current opinions. Clin. Chim. Acta 383, 57-64 http://dx.doi.org/10.1016/j.cca.2007.04.024

Alenzi F. Q., El-Bolkiny Yel-S., Salem M. L. (2010): Protective effects of Nigella sativa oil and thymoquinone against toxicity induced by the anticancer drug cyclophosphamide. Br. J. Biomed. Sci. 67, 20-28

Ammar el-S. M., Gameil N. M., Shawky N. M., Nader M. A. (2011): Comparative evaluation of anti-inflammatory properties of thymoquinone and curcumin using an asthmatic murine model. Int. Immunopharmacol. 11, 2232-2236 http://dx.doi.org/10.1016/j.intimp.2011.10.013

Arthur J. R., Boyne R. (1985): Superoxide dismutase and glutathione peroxidase activities in neutrophils from selenium deficient and copper deficient cattle. Life Sci. 36, 1569-1575 http://dx.doi.org/10.1016/0024-3205(85)90381-9

Ayinde O. C., Ogunnowo S., Ogedegbe R. A. (2012): Influence of Vitamin $\mathrm{C}$ and Vitamin $\mathrm{E}$ on testicular zinc content and testicular toxicity in lead exposed albino rats. BMC Pharmacol. Toxicol. 14, 13-17

Badary O. A., Taha R. A., Gamal el-Din A. M., Abdel-Wahab M. H. (2003): Thymoquinone is a potent superoxide anion scavenger. Drug Chem. Toxicol. 26, 87-98 http://dx.doi.org/10.1081/DCT-120020404

Barán E. J. (1994): Química Bioinorgánica. McGraw-Hill Interamericana, Madrid (in Spain)

Bent S. (2008): Herbal medicine in the United States: review of efficacy, safety, and regulation: grand rounds at University of California, San Francisco Medical Center. J. Gen. Intern. Med. 23, 854-859 http://dx.doi.org/10.1007/s11606-008-0632-y

Bolin C. M., Basha R., Cox D., Zawia N. H., Maloney B., Lahiri D. K., Cardozo-Pelaez F. (2006): Exposure to lead and the developmental origin of oxidative DNA damage in the aging brain. FASEB J. 20, 788-790

Boots A. W., Haenen G. R., Bast A. (2008): Health effects of quercetin: from antioxidant to nutraceutical. Eur. J. Pharmacol. $\mathbf{5 8 5}, \mathbf{3 2 5 - 3 3 7}$ http://dx.doi.org/10.1016/j.ejphar.2008.03.008

Çaylak E., Halifeoğlu İ., Aydin S., Telo S., Bulmuş Ö., Çelik H. (2007): The effects of sulfur-containing compounds on total antioxidant capacity levels of liver, kidney and brain in leadexposed rats. Turkiye Klinikleri J. Med. Sci. 27, 823-828
Çaylak E., Aytekin M., Halifeoğlu İ. (2008): Antioxidant effects of methionine, $\alpha$-lipoic acid, $\mathrm{N}$-acetylcysteine and homocysteine on lead-induced oxidative stress to erythrocytes in rats. Exp. Toxicol. Pathol. 60, 289-294 http://dx.doi.org/10.1016/j.etp.2007.11.004

Çelik F., Göçmez C., Karaman H., Kamaşak K., Kaplan İ., Akıl E., Tufek A., Guzel A., Uzar E. (2014): Therapeutic effects of thymoquinone in a model of neuropathic pain. Curr. Ther. Res. 76, 11-16 http://dx.doi.org/10.1016/j.curtheres.2013.11.001

Chiba M., Shinohara A., Matsushita K., Watanabe H., Inaba Y. (1996): Indices of lead-exposure in blood and urine of lead-exposed workers and concentrations of major and trace elements and activities of SOD, GSH-Px and catalase in their blood. Tohoku J. Exp. Med. 178, 49-62 http://dx.doi.org/10.1620/tjem.178.49

Christie N. T., Costa M. (1984): In vitro assessment of the toxicity of metal compounds. IV. Disposition of metals in cells: interaction with membranes, glutathione, metallothionein, and DNA. Biol. Trace Elem. Res. 6, 139-158 http://dx.doi.org/10.1007/BF02916931

Cohen G., Kim M., Ogwu V. (1996): A modified catalase assay suitable for a plate reader and for the analysis of brain cell cultures. J. Neurosci. Methods 67, 53-56 http://dx.doi.org/10.1016/0165-0270(96)00011-8

Dorostghoal M., Seyyednejad S. M., Jabari A. (2014): Protective effects of Fumaria parviflora L. on lead-induced testicular toxicity in male rats. Andrologia 46, 437-446 http://dx.doi.org/10.1111/and.12100

Dresel E. I., Falk J. E. (1954): Studies on the biosynthesis of blood pigment. I. Haem synthesis in hemolysed erythrocytes of chicken blood. Biochem. J. 56, 156-163

Dröge W. (2002): Free radicals in the physiological control of cell function. Physiol. Rev. 82, 47-95

Ellman G. L. (1959): Tissue sulfhydryl groups. Arch. Biochem. Biophys. 82, 70-77 http://dx.doi.org/10.1016/0003-9861(59)90090-6

El-Sayed W. M. (2011): Upregulation of chemoprotective enzymes and glutathione by Nigella sativa (black seed) and thymoquinone in CCl4-intoxicated rats. Int. J. Toxicol. 30, 707-714 http://dx.doi.org/10.1177/1091581811420741

Fair J. M., Ricklefs R. E. (2002): Physiological, growth and immune responses of Japanese quail chicks to the multiple stressors of immunological challenge and lead shot. Arch. Environ. Contam. Toxicol. 42, 77-87 http://dx.doi.org/10.1007/s002440010294

Flora S. J., Bhattacharya R., Vijayaraghavan R. (1995): Combined therapeutic potential of meso-2,3-dimercaptosuccinic acid and calcium disodium edetate on the mobilization and distribution of lead in experimental lead intoxication in rats. Fundam. Appl. Toxicol. 25, 233-240 http://dx.doi.org/10.1093/toxsci/25.2.233

Gordon J. N., Taylor A., Bennett P. N. (2002): Lead poisoning: case studies. Br. J. Clin. Pharmacol. 53, 451-458 http://dx.doi.org/10.1046/j.1365-2125.2002.01580.x

Halliwell B., Gutteridge J. M. C. (1989): Free Radicals in Biology and Medicine. (2nd edition), Clarendon Press, Oxford 
Hammond P. B. (1977): Exposure of humans to lead. Annu. Rev. Pharmacol. Toxicol. 17, 197-214 http://dx.doi.org/10.1146/annurev.pa.17.040177.001213

Henretig F. M. (2002): Lead. In: Gold Frank's Toxicological Emergencies. (Eds. G. Lewis, N. Lewis, M. A. Howland, L. Nelson), pp. 1200-1237, McGraw-Hill, New York

Hsu P. C., Guo Y. L. (2002): Antioxidant nutrients and lead toxicity. Toxicology 180, 33-44 http://dx.doi.org/10.1016/S0300-483X(02)00380-3

Ismail M., Al-Naqeep G., Chan K. W. (2010): Nigella sativa thymoquinone-rich fraction greatly improves plasma antioxidant capacity and expression of antioxidant genes in hypercholesterolemic rats. Free Radic. Biol. Med. 48, 664-672 http://dx.doi.org/10.1016/j.freeradbiomed.2009.12.002

Kanter M., Coskun O., Uysal H. (2006): The antioxidative and antihistaminic effect of Nigella sativa and its major constituent, thymoquinone on ethanol-induced gastric mucosal damage. Arch. Toxicol. 80, 217-224 http://dx.doi.org/10.1007/s00204-005-0037-1

Karrari P., Mehrpour O., Abdollahi M. (2012): A systematic review on status of lead pollution and toxicity in Iran; guidance for preventive measures. Daru 20, 1-17 http://dx.doi.org/10.1186/1560-8115-20-2

Khalil-Manesh F., Tartaglia-Erler J., Gonick H. C. (1994): Experimental model of lead nephropathy. IV. Correlation between renal functional changes and hematological indices of lead toxicity. J. Trace Elem. Electrolytes Health Dis. 8, 13-19

Korsrud G. O., Meldrum J. B. (1988): Effect of diet on the response in rats to lead acetate given orally or in the drinking water. Biol. Trace Elem. Res. 17, 167-173 http://dx.doi.org/10.1007/BF02795454

Kruk I. (1998): Environmental Toxicology and Chemistry of Oxygen Species. The Handbook of Environmental Chemistry, Vol. 2. Springer, Berlin http://dx.doi.org/10.1007/978-3-540-49571-0

Lee P. J., Choi A. M. (2003): Pathways of cell signaling in hyperoxia. Free Radic. Biol. Med. 35, 341-350 http://dx.doi.org/10.1016/S0891-5849(03)00279-X

Lupidi G., Scire A., Camaioni E., Khalife K. H., De Sanctis G., Tanfani F., Damiani E. (2010): Thymoquinone, a potential therapeutic agent of Nigella sativa, binds to site I of human serum albumin. Phytomedicine 17, 714-720 http://dx.doi.org/10.1016/j.phymed.2010.01.011

Mansour M. A., Nagi M. N., El-Khatib A. S., Al-Bekairi A. M. (2002): Effects of thymoquinone on antioxidant enzyme activities, lipid peroxidation and DT-diaphorase in different tissues of mice: a possible mechanism of action. Cell Biochem. Funct. 20, 143-151 http://dx.doi.org/10.1002/cbf.968

Marchlewicz M., Michalska T., Wiszniewska B. (2004): Detection of lead-induced oxidative stress in the rat epididymis by chemiluminescence. Chemosphere 57, 1553-1562 http://dx.doi.org/10.1016/j.chemosphere.2004.08.102

Marchlewicz M., Wiszniewska B., Gonet B., Baranowska-Bosiacka I., Safranow K., Kolasa A., Głabowski W., Kurzawa R., Jakubowska K., Rać M. E. (2007): Increased lipid peroxidation and ascorbic acid utilization in testis and epididymis of rats chronically exposed to lead. Biometals 20, 13-19 http://dx.doi.org/10.1007/s10534-006-9009-Z
McGowan C., Donaldson W. E. (1986): Changes in organ nonprotein sulfhydryl and glutathione concentrations during acute and chronic administration of inorganic lead to chicks. Biol. Trace Elem. Res. 10, 37-46 http://dx.doi.org/10.1007/BF02795317

Mishra M., Acharya U. R. (2004): Protective action of vitamins on the spermatogenesis in lead-treated Swiss mice. J. Trace Elem. Med. Biol. 18, 173-178 http://dx.doi.org/10.1016/j.jtemb.2004.03.007

Nagi M. N., Al-Shabanah O. A., Hafez M. M., Sayed-Ahmed M. M. (2011): Thymoquinone supplementation attenuates cyclophosphamide-induced cardiotoxicity in rats. J. Biochem. Mol. Toxicol. 25, 135-142 http://dx.doi.org/10.1002/jbt.20369

Neal R., Cooper K., Kellogg G., Gurer H., Ercal N. (1999): Effects of some sulfur-containing antioxidant on lead-exposed lenses. Free Radic. Biol. Med. 26, 239-243 http://dx.doi.org/10.1016/S0891-5849(98)00214-7

Nili-Ahmadabadi A., Tavakoli F., Hasanzadeh G. R., Rahimi H., Sabzevari O. (2011): Protective effect of pretreatment with thymoquinone against Aflatoxin B1 induced liver toxicity in mice. Daru 19, 282-287

Ng H. Y., Tain Y. L., Lee Y. T., Hsu C. Y., Chiou T. T., Huang P. C., Lee C. T. (2013): Renin angiotensin system blockade ameliorates lead nephropathy. Biochem. Biophys. Res. Commun. 438, 359-363 http://dx.doi.org/10.1016/j.bbrc.2013.07.076

Paglia D. E., Valentine W. N. (1967): Studies on the quantitative and qualitative characterization of erythrocyte glutathione peroxidase. J. Lab. Clin. Med. 70, 158-169

Pande M., Mehta A., Pant B. P., Flora S. J. (2001): Combined administration of a chelating agent and an antioxidant in the prevention and treatment of acute lead intoxication in rats. Environ. Toxicol. Pharm. 9, 173-184 http://dx.doi.org/10.1016/S1382-6689(01)00064-3

Patocka J., Cerný K. (2003): Inorganic lead toxicology. Acta Medica (Hradec Kralove) 46, 65-72

Patra R. C., Swarup D., Dwivedi S. K. (2001) Antioxidant effects of alpha tocopherol, ascorbic acid and L-methionine on lead induced oxidative stress to the liver, kidney and brain in rats. Toxicology 162, 81-88 http://dx.doi.org/10.1016/S0300-483X(01)00345-6

Placer Z. A., Cushman L. L., Johnson B.C. (1966): Estimation of product of lipid peroxidation (malonyl dialdehyde) in biochemical systems. Anal. Biochem. 16, 359-364 http://dx.doi.org/10.1016/0003-2697(66)90167-9

Rifaioglu M.M., Nacar A., Yuksel R., Yonden Z., Karcioglu M., Zobra O. U. (2013): Antioxidative and anti-inflammatory effect of thymoquinone in an acute Pseudomonas Prostatitis rat model. Urol. Int. 91, 474-481 http://dx.doi.org/10.1159/000351261

Salawu E. O., Adeeyo O. A., Falokun O. P., Yusuf U. A., Oyerinde A., Adeleke A. A. (2009): Tomato (Lycoperscion esculentum) prevents lead-induced testicular toxicity. J. Hum. Reprod. Sci. $2,30-34$ http://dx.doi.org/10.4103/0974-1208.51346

Sayed-Ahmed M. M., Nagi M. N. (2007): Thymoquinone supplementation prevents the development of gentamicin-induced 
acute renal toxicity in rats. Clin. Exp. Pharmacol. Physiol. 34, 399-405

http://dx.doi.org/10.1111/j.1440-1681.2007.04560.x

Sayed-Ahmed M. M., Aleisa A. M., Al-Rejaie S. S., Al-Yahya A. A., Al-Shabanah O. A., Hafez M. M., Nagi M. N. (2010): Thymoquinone attenuates diethylnitrosamine induction of hepatic carcinogenesis through antioxidant signaling. Oxid. Med. Cell. Longev. 3, 254-261 http://dx.doi.org/10.4161/oxim.3.4.12714

Schrauzer G. N. (1987): Effects of selenium antagonists on cancer susceptibility: new aspects of chronic heavy metal toxicity. J. UOEH (Suppl.) 9, 208-215

Singh R. P., Shashwat S., Suman K. (2004): Free radicals and oxidative stress in neurodegenerative diseases: relevance of dietary antioxidants. JIACM 5, 218-225

Sivaprasad R., Nagaraj M., Varalakshmi P. (2002): Lipoic acid in combination with a chelator ameliorates lead-induced peroxidative damages in rat kidney. Arch. Toxicol. 76, 437-441 http://dx.doi.org/10.1007/s00204-002-0350-x

Sivaprasad R., Nagaraj M., Varalakshmi P. (2004): Combined efficacies of lipoic acid and 2,3-dimercaptosuccinic acid against lead-induced lipid peroxidation in rat liver. J. Nutr. Biochem. 15, 18-23 http://dx.doi.org/10.1016/j.jnutbio.2003.09.001

Snoeijs T., Dauwe T., Pinxten R., Vandesande F., Eens M. (2004) Heavy metal exposure affects the humoral immune response in a free-living small songbird, the great tit (Parus major). Arch. Environ. Contam. Toxicol. 46, 399-404 http://dx.doi.org/10.1007/s00244-003-2195-6

Todorova I., Simeonova G., Kyuchukova D., Dinev D., Gadjeva V. (2005): Reference values of oxidative stress parameters (MDA, SOD, CAT) in dogs and cats. Comp. Clin. Pathol. 13, 190-194 http://dx.doi.org/10.1007/s00580-005-0547-5

Vallee B. L., Ulmer D. D. (1972): Biochemical effects of mercury, cadmium, and lead. Annu. Rev. Biochem. 41, 91-128 http://dx.doi.org/10.1146/annurev.bi.41.070172.000515

Wang C., Zhang Y., Liang J., Shan G., Wang Y., Shi Q. (2006): Impacts of ascorbic acid and thiamine supplementation at different concentrations on lead toxicity in testis. Clin. Chim. Acta 370, 82-88 http://dx.doi.org/10.1016/j.cca.2006.01.023

Wasowicz W., Gromadzińska J., Rydzyński K. (2001): Blood concentration of essential trace elements and heavy metals in workers exposed to lead and cadmium. Int. J. Occup. Med. Environ. Health 14, 223-229

Woo C. C., Loo S. Y., Gee V., Yap C. W., Sethi G., Kumar A. P., Tan K. H. (2011): Anticancer activity of thymoquinone in breast cancer cells: possible involvement of PPAR- $\gamma$ pathway. Biochem. Pharmacol. 82, 464-475 http://dx.doi.org/10.1016/j.bcp.2011.05.030

Yaman I., Balikci E. (2010): Protective effects of Nigella sativa against gentamicin-induced nephrotoxicity in rats. Exp. Toxicol. Pathol. 62, 183-190 http://dx.doi.org/10.1016/j.etp.2009.03.006

Zhang Z. F., Fan S. H., Zheng Y. L., Lu J., Wu D. M., Shan Q., Hu B. (2009): Purple sweet potato color attenuates oxidative stress and inflammatory response induced by d-galactose in mouse liver. Food Chem. Toxicol. 47, 496-501 http://dx.doi.org/10.1016/j.fct.2008.12.005

Received: March 31, 2014

Final version accepted: July 18, 2014

First published online: November 4, 2014 